\title{
Android-Based Physics Learning Media Integrated Landslide Disaster
}

\author{
Ulfaturrona Nur Labibah*1, Insih Wilujeng ${ }^{2}$, Syazana Sulaiman $^{3}$, Lia Rahmawati $^{4}$ \\ ${ }^{1,2,4}$ Physics Education Department, Universitas Negeri Yogyakarta, Colombo Street Number 1 Karang Malang, \\ Depok, Sleman, Yogyakarta, Indonesia \\ ${ }^{3}$ Material Science, Universiti Putra Malaysia, Institut Teknologi Maju (ITMA) 43400, Selangor, Malaysia
}

*Correspondence address: ulfaturronanurlabibah@gmail.com

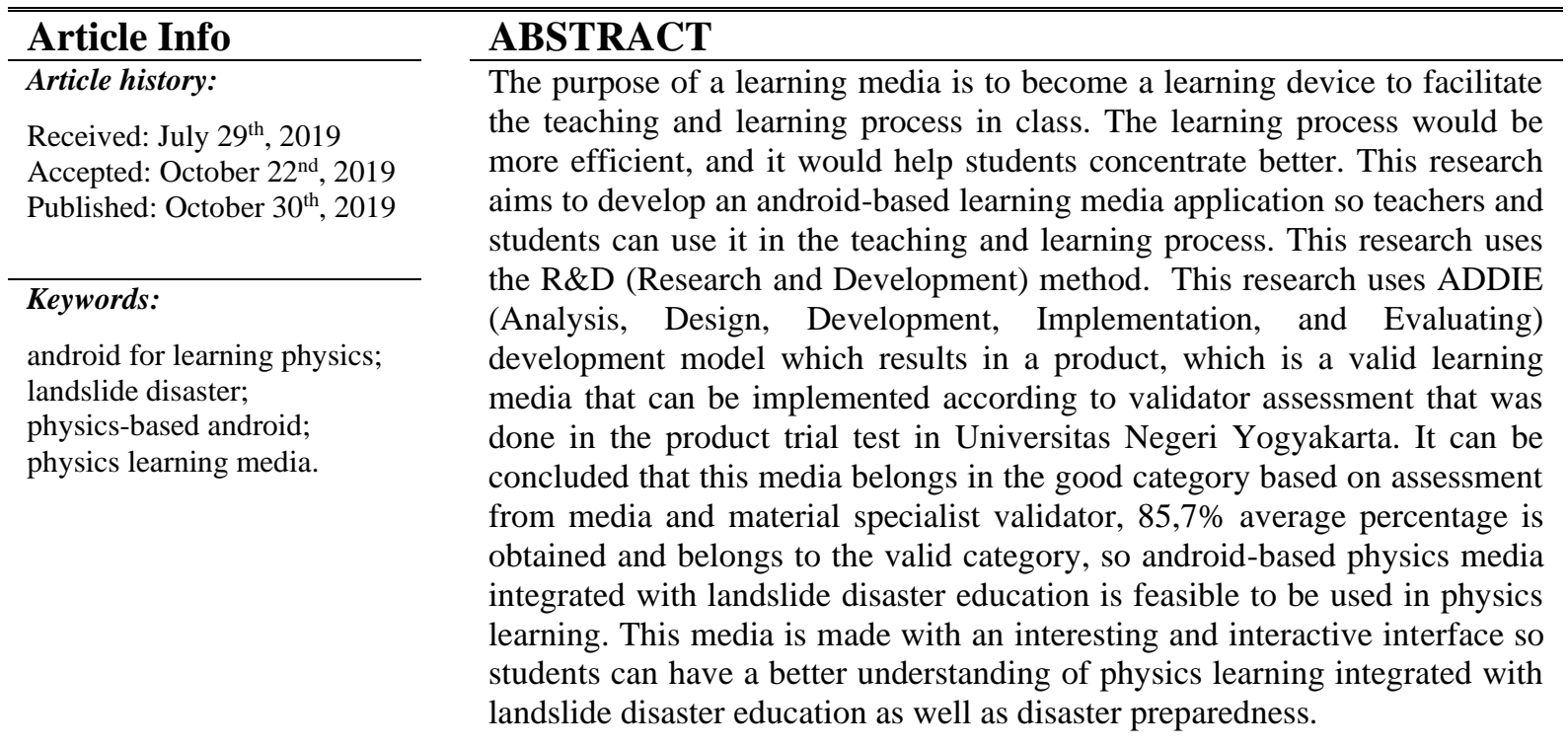

(C) 2019 Physics Education Department, UIN Raden Intan Lampung, Indonesia.

\section{INTRODUCTION}

Development and advancement of technology in the modern era can be expanded to the education sector, one of which is an android application because nowadays many students have already used gadgets. Technology development can be used to make a learning media with android (Isma Ramadhani Lubis \& Jaslin Ikhsan, 2015; Taufiq, Amalia, Parmin, \& Leviana, 2016; Vilmala \& Mundilarto, 2019; Yektyastuti \& Ikhsan, 2016). Android-based learning media implemented in schools can increase different experiences to students during the learning process (Hadi \& Dwijananti, 2015; Taufiq et al., 2016).

Media is one of a tool to convey a message (Sanaky, 2013; Viyanti, Parmin, \&
Akhlis, 2014). The aim of learning media is to be a learning device that facilitates the teaching and learning process in class, the Learning process would be more efficient and would help students concentrate better (Widayat, Kasmui, \& Sukesih, 2014). Android is a mobile operating system that can grow and develop in the middle of other operating systems. Android is highly demanded because developers have the freedom to create an open-source application (Dian Anggraeni \& Kustijono, 2013).

Right now, natural disasters have worsened and become more varied because of social and climate change. Disasters also happen because of geographical location on the earth's surface. Earth's surface contains a 
lot of mountains and slope that can trigger natural disasters such as landslides (Alcántara-Ayala et al., 2017; Kim, Jung, Kim, \& Chung, 2016). Landslide occurs a lot in Indonesia especially in the mountain areas and where rain occurs a lot (Angga, Feranie, Tohari, \& D.E. Latief, 2016; Hasanah, Wahyuni, \& Bachtiar, 2016).

Society still does not know how to face disasters because lack of education and efforts to minimize damage is needed (Anggraini, Wahyuni, \& Aristya, 2017; Putranto \& Susanto, 2017; Souisa, Hendrajaya, \& Handayani, 2018; Syuaib, 2013; Wimbardana \& Sagala, 2013). Landslide disaster is very harmful and occurs a lot, because of many factors. One of the factors of the landslide is when fluids enter the crevice so the dike scoured and the soil is dominated with clay (Souisa et al., 2018). Anomalies spreading and relating to the surrounding area where the landslide occurred so continuation might happen if high-intensity rain occurs (Souisa et al., 2018).

Indonesia needs natural disaster management, one of them is through the education sector (Septikasari, 2018; Wedyawati, Lisa, \& Selimayati, 2017). Education on natural disasters needs to be taught to students since the early stage so they do not destroy nature and act to prevent natural disasters. Responsiveness towards natural disasters especially on students, Indonesia's curriculum needs an education curriculum based on local wisdom (Desfandi, 2014; Rusilowati \& Widiyatmoko, 2015). Integrated local and indigenous knowledge with science is an important process that allows practitioners and scientists to carry out activities and research (Hiwasaki, Luna, Syamsidik, \& Shaw, 2014).

Based on science perspectives, disaster curriculum can be integrated into the learning process in schools that have a strong relation to disasters. Physics learning can be integrated into disaster education through an appropriate learning model.
Disaster simulation can be implemented in disaster awareness training in society and schools as well as in urban disaster planning. Information processes given with a warning analogy, comparing and evaluating so basic conceptual understanding can be remembered long term (Docktor \& Mestre, 2014). One of the ways to spread information is by using technology.

Some research that has been conducted in developing an android-based learning media in physic material which is projectile motion (Satria Adhi Kusuma marhadini, Isa Akhlis, \& Imam Sumpono, 2017); pressure (Astuti, Sumarni, \& Saraswati, 2017); and static fluid (Handayani \& Suharyanto, 2016) the media layout is still simple so it does not attract students and there is no relation to disaster education. Research on disaster education in schools only studies from a few disciplines, so there is still no medium to implement android-based media disaster education through learning activities in schools with android-based media in disaster management (Honesti \& Djali, 2012).

According to the background, to help teachers deliver physics material integrated with landslide disaster education, an android-based media integrated with landslide disaster education needed to be developed. The purpose of this development is to produce a valid androidbased application so teachers and students can use it in teaching and learning activities. Media developed in this research uses Photoshop, Adobe Audition and Android Studio and then imported with (.apk) extension and operated offline by smartphone to ease teachers and students whenever and wherever. This media is integrated with landslide disaster education that occurs a lot in Indonesia with climate change physics material and is made clear and interesting with disaster preparedness and student's understanding evaluation. 


\section{METHODS}

This research was done with an $\mathrm{R} \& \mathrm{D}$ (Research and Development) method. The research procedure adapts the ADDIE development model, which consists of five steps which are Analysis, Design, Development, Implementation, and Evaluating. This research is developed to facilitate teachers in giving learning materials in class so it is easier for students to understand it. A learning media validity test is done by a media specialist validator and material specialist validator. Then, the validator is asked to give assessment generally and suggestions towards this learning media development, below are the steps of android-based physics learning media development integrated with landslide disaster education using ADDIE model in figure 1.

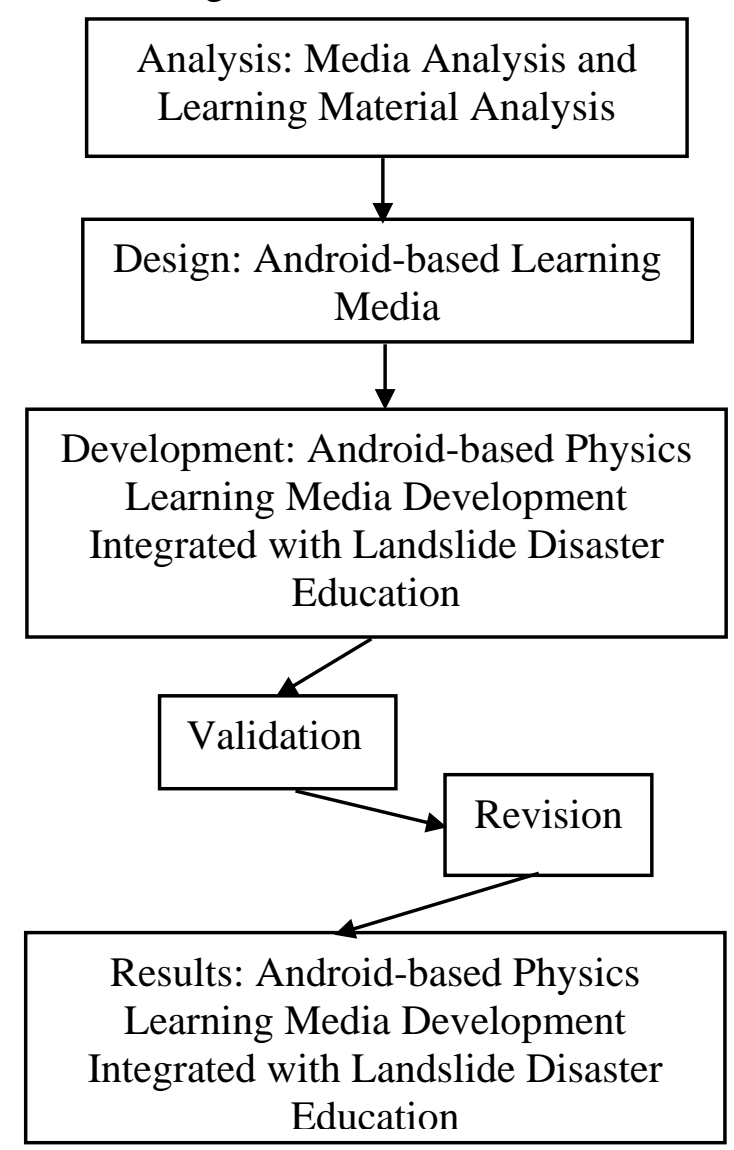

Figure 1. Steps of android-based physics learning media development integrated with landslide disaster education using the ADDIE model.
Media feasibility is analyzed by the developed media quality category. The media quality category is obtained from a media expert validation questionnaire and material expert validation. Media quality data is 1-5 Likert scale data and are analyzed by calculating the average score from every assessment aspect. To convert the data to scaled standard scores (Widoyoko, 2013), ideal assessment criteria are used that can be seen in Table 1 ,

Table 1. Ideal Assessment Criteria

\begin{tabular}{|c|c|c|c|}
\hline No. & Score Interval & Value & $\begin{array}{l}\text { Quality } \\
\text { Criteria }\end{array}$ \\
\hline 1 & $\bar{X}_{2} \bar{X}_{n}+1,8 \mathrm{SB}_{\mathrm{i}}<\mathrm{X}$ & A & $\begin{array}{l}\text { Very } \\
\text { Good }\end{array}$ \\
\hline 2 & $\begin{array}{c}\bar{X}_{n} \bar{X}_{n}+0,6 \mathrm{SB}_{\mathrm{i}}<\mathrm{X} \\
<\overline{X_{n}} \bar{X}_{n}+1,8 \mathrm{SB}_{\mathrm{i}}\end{array}$ & B & Good \\
\hline 3 & $\begin{array}{c}\bar{X}_{2} \bar{X}_{n}-0,6 \mathrm{SB}_{\mathrm{i}}<\mathrm{X} \\
<\bar{X}_{n} \bar{X}_{n}+0,6 \mathrm{SB}_{\mathrm{i}}\end{array}$ & $\mathrm{C}$ & Enough \\
\hline 4 & $\begin{array}{c}\bar{X}_{2} \bar{X}_{n}-1,8 \mathrm{SB}_{\mathrm{i}}<\mathrm{X} \\
\quad<\bar{X}_{n} \bar{X}_{n}-0,6 \mathrm{SB}_{\mathrm{i}}\end{array}$ & $\mathrm{D}$ & Less \\
\hline 5 & $\begin{array}{c}\overline{X<X_{2}} \overline{X<X_{2}}- \\
1,8 \mathrm{SB}_{\mathrm{i}}\end{array}$ & $\mathrm{E}$ & $\begin{array}{l}\text { Very } \\
\text { Less }\end{array}$ \\
\hline
\end{tabular}

Then converted to $1-5$ score interval $\bar{X}_{n} \bar{X}_{n}($ ideal median $)=(1 / 2)(5+1)=3$

$\mathrm{SB}_{\mathrm{i}}$ (ideal deviation standard) $=(1 / 3)(1 / 2)(5-1)=0,7$

The data analysis technique used in this research is descriptive analysis, which is calculating media validation score percentage and material validation with equation (1) below:

$$
\text { Percentage }=\frac{\text { the scores obtained }}{\begin{array}{c}
\text { the scores maximum } \\
\times 100 \%(1)
\end{array}}
$$

The bigger the validation results score percentage, the better the product feasibility from the development research. Criteria in deciding in learning media validation can be seen in Table 2 (Riduwan, 2012), 
Table 2. Learning Media Feasibility Criteria

\begin{tabular}{ccc}
\hline No. & Percentage & Description \\
\hline $\mathbf{1}$ & $80 \%-100 \%$ & Good/Valid \\
\hline $\mathbf{2}$ & $60 \%-79,99 \%$ & $\begin{array}{c}\text { Pretty Good/ } \\
\text { Pretty Valid }\end{array}$ \\
\hline $\mathbf{3}$ & $50 \%-59,99 \%$ & Poor/ Less Valid \\
\hline $\mathbf{4}$ & $0-49,99 \%$ & $\begin{array}{c}\text { Not Good/ Not } \\
\text { Valid }\end{array}$ \\
\hline
\end{tabular}

\section{RESULTS AND DISCUSSION}

The product developed in this research is an android-based physics learning media development integrated with landslide disaster education application. The media produced is expected to be used by students whenever and wherever. Research development using the ADDIE model is only done until the development steps because this research aims to only develop and produce a valid learning media to be implemented based on validator assessment.

Steps of the research development are: 1) Analysis, the material is chosen is global warming symptoms integrated with landslide disaster. Because this material consists of the concrete subject so this android-based media, teachers can give a concrete explanation from the abstract material; 2) Design, In this step, there are several things done which are: a) design an android-based learning media application; b) Material, pictures and videos suitable and appropriate with global warming symptoms material; c) Validation sheet from media and material specialists; 3) Development, result from this step are: a) Android-based learning media application, this application includes learning preface, teaching material (pictures and videos are included), landslide disaster preparedness, this application consists of learning preface, teaching material (pictures and videos included), evaluation test, and b) media validation score.

\section{Media Interface}

The media interface consists of a preface menu, material, disaster preparedness, evacuation, instructions to use, sound, references, profile and exit button. It can be seen in figure 2 ,

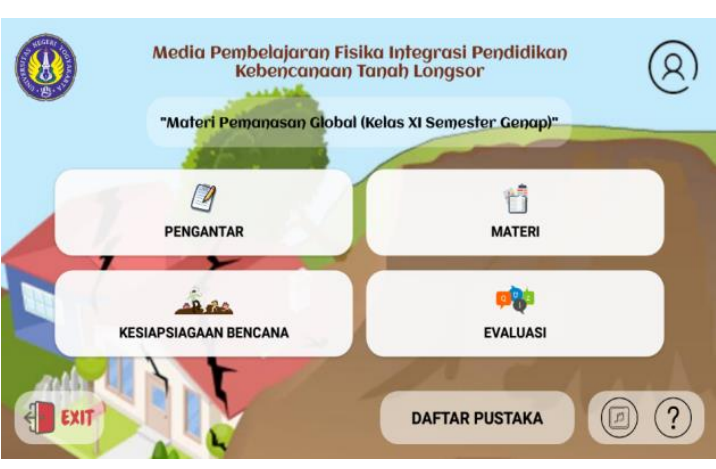

Figure 2. First Page of the Android-based Learning Media.

The first page consists of Main Competency (KI), Basic Competency (KD), Indicator, Learning Objectives and Concept Map as seen in figure 3,

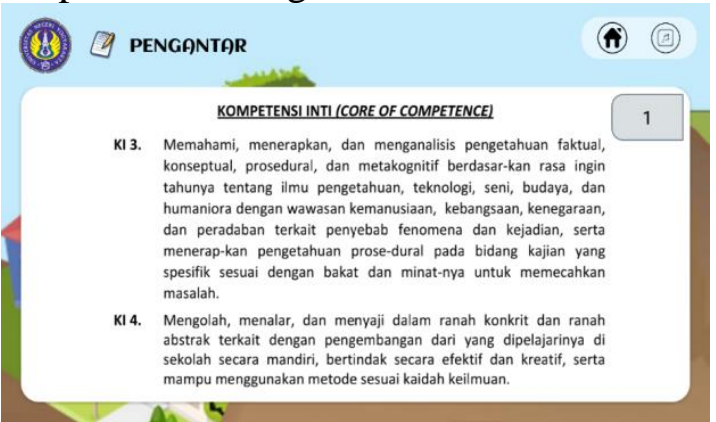

Figure 3. First Page of the Android-based Learning Media

The material page consists of a global warming page integrated with landslide disaster as seen as figure 4,

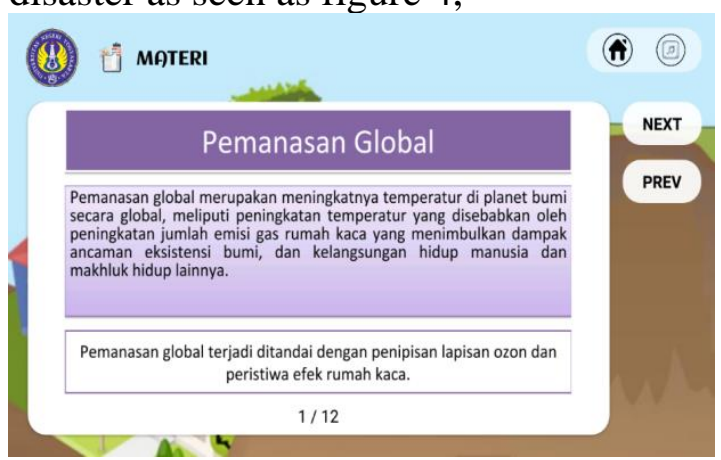

Figure 4. Material Page of the Android-based learning media

The preparedness page consists of landslide preparedness video referring to the National Disaster Mitigation Agency (BNPB) Bencana (BNPB) as seen on figure 5 , 


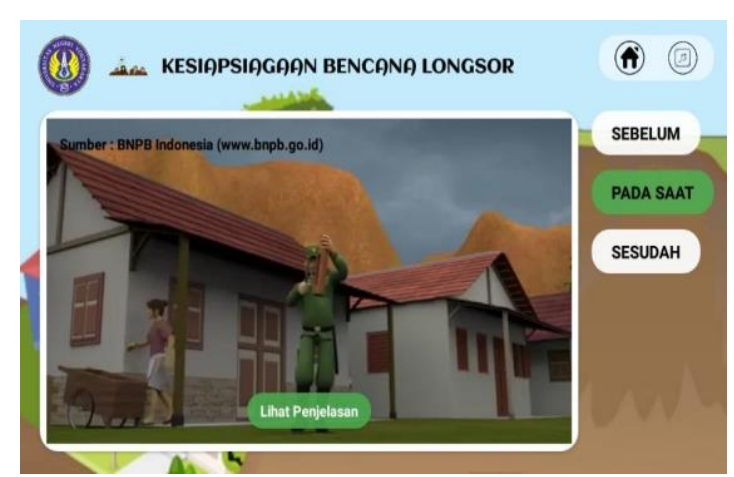

Figure 5. Preparedness Page of the Android-based learning media

The evaluation page consists of a guide to do the test and 5 multiple choice questions and there is a result page after doing the test as seen in figure 6 ,

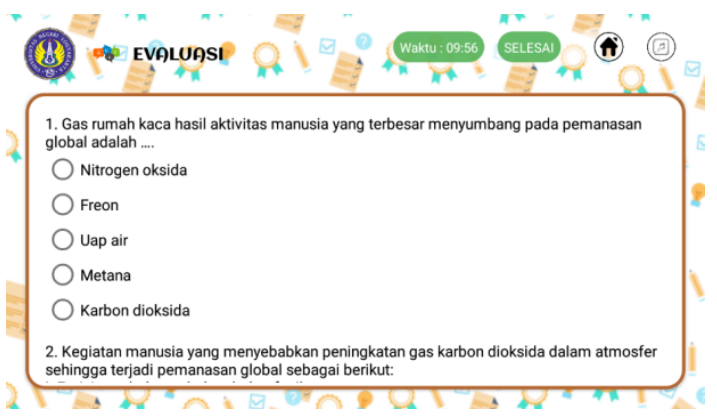

Figure 6. Evaluation Page of the Android-based learning media

\section{Media Validation Result}

Quantitative score conversion into a qualitative category and media validation result by referring to the assessment calculation criteria in Table 3 below.

Table 3. Quantitative score conversion to qualitative category on Android-based learning Media Validation by Material and media expert

\begin{tabular}{cccc}
\hline No. & Score Interval & Value & $\begin{array}{c}\text { Quality } \\
\text { Criteria }\end{array}$ \\
\hline $\mathbf{1}$ & $4,26<\mathrm{X}$ & $\mathrm{A}$ & Very Good \\
\hline $\mathbf{2}$ & $3,423<\mathrm{X}<4,264$ & $\mathrm{~B}$ & Good \\
\hline $\mathbf{3}$ & $2,58<\mathrm{X}<3,423$ & $\mathrm{C}$ & Enough \\
\hline $\mathbf{4}$ & $1,74<\mathrm{X}<2,582$ & $\mathrm{D}$ & Less \\
\hline $\mathbf{5}$ & $\bar{X}<\bar{X}<1,74$ & $\mathrm{E}$ & Very Less \\
\hline
\end{tabular}

Validator score is compared to the above category. The average score from the media expert validation result is 4,19 and belongs to the Good category and the score from a material expert is 4,38 and belongs to the Very Good category. Then, using a descriptive method, from media validation average score and material validation become:

$$
\text { Percentage }=\frac{4,285}{5} \times 100 \%=85,7 \%
$$

Results from media and material validation average scores are $85,7 \%$ and belong to good/valid category so it is a feasible media to be used in learning activities.

Through android-based media by developing an integrated landslide disaster media, it can help students in understanding natural disasters (Alcántara-Ayala et al., 2017; Kim et al., 2016). The outcome of android-based physics learning media development integrated with landslide disaster education using $R \& D$ in Information process given with a warning analogy, comparing and evaluating so basic conceptual understanding can be remembered long term (Docktor \& Mestre, 2014). Development of physics learning media can be integrated with disaster education especially landslide because media is one of the tools to convey a message (Sanaky, 2013). This happens because the media interface is interesting and interactive and different from development of android-based media on physics material research that is not appealing in terms of media interface (Astuti et al., 2017; Handayani \& Suharyanto, 2016; Satria Adhi Kusuma marhadini et al., 2017) and implementation in disaster education using android-based media has not yet available (Honesti \& Djali, 2012).

\section{CONCLUSION}

From the results of the research, it can be concluded that android-based physics learning media integrated with landslide disaster education has been successfully created. This media belongs to the good category as a learning media. Based on the results obtained from media and material validation average score is $85,7 \%$ and belongs to the valid category, so android- 
based physics learning media development integrated with landslide disaster education is feasible to be used in physics learning.

\section{AUTHOR CONTRIBUTIONS}

UN creates ideas and designs research. IW makes teaching materials using the selected media. SS performs validation test. LR wrote the research results and edited the draft of the manuscript.

\section{REFERENCES}

Alcántara-Ayala, I., Sassa, K., Mikoš, M., Han, Q., Rhyner, J., Takara, K., ... Briceño, S. (2017). The $4^{\text {th }}$ World Landslide Forum: Landslide Research and Risk Reduction for Advancing the Culture of Living with Natural Hazards. International Journal of Disaster Risk Science. https://doi.org/10.1007/s13753-0170139-4

Angga, A., Feranie, S., Tohari, A., \& D.E. Latief, F. (2016). Karakterisasi Lereng Berpotensi Longsor Serta Upaya Mitigasi Bencananya: Studi Kasus di Badan Jalan Lembang dan CijambeSubang. Seminar Nasional Fisika 5, (pp. 47-52). Jakarta: Universitas Negeri Jakarta. https://doi.org/10.21009/0305020410

Anggraini, S. D., Wahyuni, S., \& Aristya, P. (2017). Pengembangan Modul Fisika Materi Gelombang Berbasis Kebencanaan Alam di SMA. Jurnal Edukasi, 4(1), 20-23.

Astuti, I. A. D., Sumarni, R. A., \& Saraswati, D. L. (2017). Pengembangan Media Pembelajaran Fisika Mobile Learning berbasis Android. Jurnal Penelitian \& Pengembangan Pendidikan Fisika, 3(1), 57-62.

https://doi.org/10.21009/1.03108

Desfandi, M. (2014). Urgensi Kurikulum Pendidikan Kebencanaan Berbasis Kearifan Lokal Di Indonesia. SOSIO DIDAKTIKA: Social Science Education Journal, 1(2). https://doi.org/10.15408/sd.v1i2.1261

Dian Anggraeni, R., \& Kustijono, R. (2013).

Pengembangan Media Animasi Fisika pada Materi Cahaya dengan Aplikasi Flash Berbasis Android. Jurnal Penelitian Fisika Dan Aplikasinya (JPFA), 3(1), 11. https://doi.org/10.26740/jpfa.v3n1.p1118

Docktor, J. L., \& Mestre, J. P. (2014). Synthesis of Discipline-based Education Research in Physics. Physical Review Special Topics Physics Education Research, 10(2), 158.

https://doi.org/10.1103/PhysRevSTPE R.10.020119

Hadi, W. S., \& Dwijananti, P. (2015). Pengembangan Komik Fisika Berbasis Android sebagai Suplemen Pokok Bahasan Radioaktivitas untuk Sekolah Menengah Atas. Unnes Physics Education Journal, 4(2), 15-24. https://doi.org/https://doi.org/10.15294/ upej.v4i2.7431

Handayani, T. S., \& Suharyanto. (2016). Pengembangan Mobile Learning Berbasis Android sebagai Media Pembelajaran pada Materi Fluida Statis untuk Meningkatkan Minat dan Hasil Belajar Ranah Kognitif Peserta Didik. Jurnal Pendidikan Fisika, 5(6), 384 389.

Hasanah, I., Wahyuni, S., \& Bachtiar, R. W. (2016). Pengembangan Modul Mitigasi Bencana Berbasis Potensi Lokal yang Terintegrasi dalam Pelajaran IPA di SMP. Jurnal Pembelajaran Fisika, 5(3), 226-234.

Hiwasaki, L., Luna, E., Syamsidik, \& Shaw, R. (2014). Process for Integrating Local and Indigenous Knowledge with Science for Hydro-Meteorological Disaster Risk Reduction and Climate Change Adaptation in Coastal and Small Island Communities. International Journal of Disaster Risk Reduction, 10, 15-27. https://doi.org/10.1016/j.ijdrr.2014.07.0 
07

Honesti, L., \& Djali, N. (2012). Pendidikan Kebencanaan di Sekolah - Sekolah di Indonesia Berdasarkan Beberapa Sudut Pandang Disiplin Ilmu Pengetahuan. Jurnal Momentum, 12(1), 51-56.

Isma Ramadhani Lubis, \& Jaslin Ikhsan. (2015). Pengembangan Media Pembelajaran Kimia Berbasis Android untuk Meningkatkan Motivasi Belajar dan Prestasi Kognitif Peserta Didik SMA. Jurnal Inovasi Pendidikan IPA, 1(2), 191-201.

Kim, J. C., Jung, H., Kim, S., \& Chung, K. (2016). Slope Based Intelligent 3D Disaster Simulation Using Physics Engine. Wireless Personal Communications, 86(1), 183-199. https://doi.org/10.1007/s11277-0152788-1

Putranto, T. T., \& Susanto, N. (2017). Pilot Implementation of Human-Centered Model in Disaster Management. Indonesian Journal of Geography, 49(2), 155-164. https://doi.org/10.22146/ijg.15943

Riduwan. (2012). Skala Pengukuran Variabel-variabel Penelitian, Edisi 9. Bandung: Alfabeta.

Rusilowati, A., \& Widiyatmoko, A. (2015). Pembelajaran Kebencanaan Alam Bervisi SETS Terintegrasi dalam Mata Pelajaran Fisika Berbasis Kearifan Lokal. Jurnal Pendidikan Fisika Indonesia, 11(1), 42-48. https://doi.org/10.15294/jpfi.v11i1.400 2

Sanaky, A. (2013). Media Pembelajaran Interaktif-Inovatif. Yogyakarta: Kaukuba Dipantara.

Satria adhi kusuma marhadini, Isa Akhlis, \& Imam Sumpono.

(2017). Pengembangan Media Pembelajaran Berbasis Android pada Materi Gerak Parabola untuk Siswa SMA. UPEJ Unnes Physics Education Journal, 6(3), 38-43. https://doi.org/https://doi.org/10.15294/ upej.v6i3.19315
Septikasari, Z. (2018). Strategi Integrasi Pendidikan Kebencanaan dalam Optimalisasi Ketahanan Masyarakat Menghadapi Bencana Erupsi Gunung Merapi. Jurnal Ketahanan Nasional, 24(1), 47-59. https://doi.org/http://dx.doi.org/ $10.22146 / \mathrm{jkn} .33142$

Souisa, M., Hendrajaya, L., \& Handayani, G. (2018). Analisis Bidang Longsor Menggunakan Pendekatan Terpadu Geolistrik, Geoteknik dan Geokomputer di Negeri Lima Ambon. Indonesian Journal of Applied Physics, $8(1)$, 13. https://doi.org/10.13057/ijap.v8i1.1548 2

Syuaib, M. Z. (2013). Pengaruh Strategi Pembelajaran Simulasi Vs Bermain Peran dan Sikap Siswa terhadap Pengetahuan dan Kesiapsiagaan tentang Bencana Alam. Jurnal Pendidikan Humaniora, 1(2), 177-189.

Taufiq, M., Amalia, A. V., Parmin, P., \& Leviana, A. (2016). Design of Science Mobile Learning of Eclipse Phenomena with Conservation Insight AndroidBased App Inventor 2. Jurnal Pendidikan IPA Indonesia, 5(2), 291298. https://doi.org/10.15294/jpii.v5i2.7375

Vilmala, B. K., \& Mundilarto. (2019). Pengembangan Media Pembelajaran Fisika Berbasis Android untuk Meningkatkan Hasil Belajar Siswa Ditinjau dari Motivasi. Jurnal Ilmiah Pendidikan Teknik Elektro, 3(1), 6177.

Viyanti, N., Parmin, \& Akhlis, I. (2014). Pengembangan Media Interaktif Pembelajaran IPA Terpadu Tema Mata untuk Siswa Kelas VIII. Unnes Science Education Journal, 3(1), 364-370.

Wedyawati, N., Lisa, Y., \& Selimayati, S. (2017). Pengaruh Model Pembelajaran IPA Terintegrasi Mitigasi Bencana terhadap Hasil Belajar. Jurnal Edukasi, 15(2), 261-273.

Widayat, W., Kasmui, \& Sukesih, S. (2014). 
Pengembangan Multimedia Interaktif sebagai Media Pembelajaran IPA Terpadu pada Tema Sistem Gerak pada Manusia. Unnes Science Education Journal, 3(2), 535-541.

Widoyoko, S. E. P. (2013). Evaluasi Program Pembelajaran: Panduan Praktis bagi Pendidik dan Calon Pendidik (Pustaka Pelajar, ed.). Yogyakarta.

Wimbardana, R., \& Sagala, S. A. H. (2013).

Kesiapsiagaan Masyarakat terhadap
Bahaya Lahar Dingin Gunung Merapi. Jurnal Bumi Lestari, 13(2), 394-406.

Yektyastuti, R., \& Ikhsan, J. (2016). Pengembangan Media Pembelajaran Berbasis Android pada Materi Kelarutan untuk Meningkatkan Performa Akademik Peserta Didik SMA. Jurnal Inovasi Pendidikan IPA, 2(1), 88-99. https://doi.org/http://dx.doi.org/10.2183 1/jipi.v2i1.10289 